\title{
Performance Analysis of Aduwa (Balanite Aegyptiaca) Oil used as a Brake Fluid in Mechanical Brake System
}

\author{
Danladi Ismaila
}

\begin{abstract}
The Hydraulic properties of Aduwa Oil and Dot 3 hydraulic fluid were determined experimentally using appropriate equipment and devices. The hydraulic properties of Aduwa Oil are; Viscosity at $40{ }^{\circ} \mathrm{C}$ and $100{ }^{\circ} \mathrm{C}$ are 168.23 cst and 16.15 cst flash point is $190{ }^{\circ} \mathrm{C}$, Compressibility is $1562 \mathrm{Mpa}$, PH value is 8.5 , Boiling point is $68^{\circ} \mathrm{C}$, Pour point is $-35^{\circ} \mathrm{C}$, Actuating force is $3060 \mathrm{~N}$ and torque absorbed is $306 \mathrm{Nm}$. Whereas the hydraulic properties of Dot 3 hydraulic fluid are; Viscosity at $40{ }^{\circ} \mathrm{C}$ and $100{ }^{\circ} \mathrm{C}$ are $132 \mathrm{cst}$ and 10.2 cst, flash point is $301{ }^{\circ} \mathrm{C}$, Compressibility is $1700 \mathrm{Mpa}, \mathrm{PH}$ value is 7.4 , boiling point is $186^{\circ} \mathrm{C}$, pour point is $-50{ }^{\circ} \mathrm{C}$, actuating force is $1830 \mathrm{~N}$ and torque absorbed is $183 \mathrm{Nm}$. Our investigation on the hydraulic properties of Aduwa Oil reveals that properties like pour point, $\mathrm{PH}$ value and flash point satisfied the requirement by ISO standard for hydraulic fluid, hence more work is needed to be done on viscosity, compressibility and boiling point of the oil under investigation.
\end{abstract}

Keywords - Flashpoint, viscosity, pour point, actuating force.

\section{INTRODUCTION}

$\mathrm{T}$ HE performance analysis of Aduwa oil (Balanite Aegyptiaca oil) is aimed at analyzing and investigating the property Aduwa oil (Balanite Aegyptiaca oil) from the description of its origin, the method or process of extraction and the performance as a brake fluid in an external expanding brake.

Aduwa tree (Balanite Aegyptiaca) is a perennial shrub commonly found in the northern part of Nigeria. It is a tropical plant of the family Balanitecea. The tree grows from $4.5-9$ meters in height (Keay and Stanfield, 1964). The plant has a multiplicity of uses and almost every part of the plant is useful including leaves, fruits, thorns bark and roots.

Aduwa tree (Balanite Aegytiaca) is used to treat so many diseases such as laxative, Diarrhea, Hemorrhoids, Stomach Aches, Jaundice, Yellow fever, Syphilis and Epilepsy (Michel, 2004). The kernel of Aduwa tree (Balanite Aegyptiaca) yields oil called Zachum. The oil is used as ointment and balms containing many drugs or dressing wounds, it is also shown to have anathematic activity (Oyemachi, 1998). Aduwa oil is used as cooking oil by many communities of Northern Nigeria mainly for its medicinal benefit and as a rich and affordable means for vegetable oil. Despite its wide use in cooking, there is a little or no literature on the possibility of long term consumption of this oil.

Danladi Ismaila is a Lecturer at Adamawa State Polytechnic, Yola, Nigeria.
Apparently Aduwa oil may be used in the production of hydraulic fluids, Thus, from the classification of hydraulic fluids, they are being classified into mineral based fluids (consisting of vegetable oil) and the silicone based(Khurmi 1976). Hydraulic fluids used in mechanical brake system are used to stop or slow the motion of one-part relative to the other and also reduces friction. This is possible because the hydraulic fluids used in mechanical brake system have an actuating force, which is capable of absorbing torque during operation in an external expanding brake (Ghupta J.K 1976).

Hydraulic fluids used in mechanical brake system often contains poisonous chemicals (POLYALKYLENE GLYCOL ETHERS) as component in them, which makes them toxic, so care should be taken when working with them. In addition, hydraulic fluids, used in brake system, are liable to flammability, which can cause serious burnt.

A good lubrication value is also required for a wellfunctioning hydraulic fluid used as brake fluids. There is a great effect on long-term exposure of some hydraulic fluid to the atmosphere, as some of its components are hygroscopic and will absorb water thereby reducing its boiling point and degrade in hydraulic efficiency (Judson Hale 1999).

There is also a great effect on long term use of hydraulic fluid without changing and refilling with another fresh hydraulic fluid so as to preserve the service life of the brake system and increased the overall reliability of the brake system.

This research seeks to provide an alternative brake fluid that is reliable, efficient and provide optimal actuating force.

The aim of this project is to investigate the hydraulic properties of Aduwa oil (Balanite Aegyptiaca oil) which will be compared to an existing hydraulic fluid. And also to evaluate the torque absorbing capacity of Aduwa oil, which if established can be recommended as brake fluid in an internal expanding brake system.

The objective of this project is to compare the actuating force (braking force) of this oil with an existing hydraulic fluid.

Hydraulic fluids are aimed at producing sufficient torque absorbing capacity in an internal expanding brake system, and also lubrication and preventing wearing of the mating parts.

Hydraulic fluids used in mechanical brake system are rarely available throughout the country, particularly here in Yola Adamawa State. The most available hydraulic fluids in mechanical brake system here in Yola is DOT 3, hence there is a need to exploits for more sources of hydraulic fluid with better qualities than the local existing hydraulic fluids. 


\section{Methods AND PROCEDURES}

\section{A. Extraction of the oil}

The Balanite Aegyptiaca (balanite manghami) seed oil can be extracted base on the traditional method, descried by Abufutuh (1983) and also Okoye (1999) as described below:

Procedure:

The nuts were cracked open and the kernels were obtained. The kernels were dried and grind into pure powder using pestle and motor. Water was added and the oil was collected with moisture after constant stirring and pressing to the walls of the container. The oils were finally heated to remove moisture and a good quantity of the oil extracted was recovered.

B. Experimental procedure for determining the flash point of Aduwa oil using Pensky Martens flash point tester.

Pensky martens flash point tester is used in testing the flash point for both dual purpose kerosene (DPR) and Automobile Gas Oil (A.G.O) the procedure are as follows:

- Analyzed the sample

- Measure $100 \mathrm{~cm}^{3}$ of the sample

- Take the temperature of the fluid using a thermometer

- Pour the sample into the tag close cup inside the heater of the flash point tester

- Mount your thermometer

- Light the flame using a gun lighter attached to the tester.

- Adjust your control switch of the heater to increase or decrease the level of the heat.

- Stir the fluid using a stirrer after 5 minutes until the vapour pressure is enough to quench the flame.

- Finally take the reading with the thermometer.

C. Experimental procedure for determining the boiling point of Aduwa oil

The apparatus consists of a resort stand attach with a boiling test tube, a thermometer place inside the boiling test tube together with a stirrer, and a Bunsen burner. The procedures are as follows;

- $\quad$ Pour the sample into the boiling test tube

- $\quad$ Place the thermometer into the test tube and cover the top with cork such that a little hole is left for vapour to escape, together with a stirrer.

- $\quad$ Attach the boiling test tube to a resort stand.

- Heat the boiling test tube such that the contents of the test tube boiled while stirring.

- $\quad$ Record the temperature at which the liquid inside the boiling test tube boils, this temperature is referred to as the boiling point.

D. Experimental procedure for determining the compressibility of Aduwa oil

The compressibility is determined using a bulk modulus tester.

The procedures are as follows

- $\quad 100 \mathrm{~cm}^{3}$ of the samples are measured

- The pressure vessel is completely filed with the sample.
- $\quad$ The piston of the bulk modulus tester is then forced into the vessel with a pressure of $2.5 \mathrm{Mpa}$.

- $\quad$ The volume of the sample is measured by deducing the allowance for the expansion of the pressure vessel under the test pressure.

The compressibility can be determined by:

$$
\frac{\Delta V}{V_{\text {initial }}}=\frac{1}{\beta} \times P
$$

Using Aduwa Oil Sample;

$\mathrm{V}_{\text {initial }}=$ initial volume $\left(\mathrm{cm}^{3}\right)$

$\mathrm{V}_{\text {final }} \quad=$ final volume $\left(\mathrm{cm}^{3}\right)$

$\Delta \mathrm{v} \quad=\quad \mathrm{V}_{\text {final }}-\mathrm{V}_{\text {initial }}$

Where $\beta$ is the compressibility in Mpa

$\mathrm{P}$ is the pressure applied (Mpa)

E. Experimental procedure for determining pour point of Aduwa oil.

The pour is determined using Seta-LEC Cloud and pour point refrigerator.

The procedures are as follows;

- $100 \mathrm{~cm}^{3}$ of the samples is measure and poured into the bath.

- The bath is connected to a tube that runs in a close circle loop manner so that the fluid will be flowing

- The machine is switched on, which cools progressively until the oil seize to flow.

- The temperature at that particular point is taken in degree Celsius $\left({ }^{0} \mathrm{C}\right)$

F. Experimental procedure for determining the viscosity of Aduwa oil

The apparatus used is viscometer. The viscosity is determined for both sample using viscometer at $40^{\circ} \mathrm{C}$ and $100^{\circ} \mathrm{C}$.

The procedures are as follows;

- The sample is measured and filled into the charging tube.

- The viscometer uses a piston driven electromagnetically through the fluid in measurement chamber.

- A deflector positioned over the piston moves the fluid into the measurement chamber

- Two coils move the piston back and forth at a constant force. The entire process is set at $40^{\circ} \mathrm{C}$ while the readings were taken.

- The process is then set at $100^{\circ} \mathrm{C}$, where readings were also taken.

G. Experimental procedure for determining the actuating force for DOT 3 hydraulic fluid and Aduwa oil using friction rig machine

The friction testing rig machine consists of a brake pedal connect by transmission lines, the main brake mechanism which consists of a rotating disc (drum), a caliper, a cylinder and a spring.

The machine has a barometer used for measuring the pressure on the brake pedal, an electric motor which rotates disc (drum), a speedometer which measures the speed of the 
electric motor and a thermometer that measure the temperature.

The procedures are as follows;

- $\quad$ The sample of Hydraulic Oil (DOT 3) volume $140 \mathrm{ml}$ was put into the tank of the friction rig machine.

- The machine was switch on and the initial readings were taking for temperature, speed and pressure.

- $\quad$ After 5 minutes the brake pedal was pressed and the final readings were taking.

- $\quad$ The same procedure was repeated using Aduwa oil of same volume.

The Equation for Determining the Actuating Force is given below:

$$
F_{t}=\frac{E}{\pi N t}
$$

Where, $\mathrm{F}_{\mathrm{t}}$ is the Actuating Force $(\mathrm{N})$

$\mathrm{E} \quad$ is the Energy $\operatorname{absorb}(\mathrm{J})$

$\mathrm{d} \quad$ is the diameter of the drum (m)

$\mathrm{N} \quad$ is the speed of the drum (r.p.m)

$\mathrm{t} \quad$ is the braking time (s)

$$
\text { Pressure } \quad=\frac{F}{A}
$$

From the table, the pressure for Aduwa oil

$\mathrm{P}=1.04 \mathrm{kgf} / \mathrm{cm}^{2}$

$\mathrm{P}=102 \times 10^{3} \mathrm{~N} / \mathrm{m}^{2}$

The diameter of brake drum $=0.2 \mathrm{~m}$

$$
\text { Where } \mathrm{A}=\frac{\pi d^{2}}{4}
$$

Torque $(\mathrm{T})=\mathrm{F}_{\mathrm{t}} \times \mathrm{r}$

$$
=F_{t} \times \frac{d}{2}
$$

H. Experimental procedure for determining the $P H$ value of DOT 3 hydraulic fluid and Aduwa oil

Universal indicator is used in the measurement of the $\mathrm{pH}$ values and the procedures are as follows; the indicator is such that it covers the ranges of the $\mathrm{pH}$ value.

- $25 \mathrm{~cm}^{3}$ of the sample (Aduwa) oil is measured and poured into a conical flask.

- Three drops of the standard indicator were added to the sample in the conical flask

- The colour was then observed and compared with a buffer solution of known $\mathrm{pH}$ containing the same amount of the standard indicator.

- The colour changes from yellow to light red indicating a phenol red with a $\mathrm{pH}$ value of 8.5.

- The same procedures were repeated using hydraulic fluid (DOT 3) samples.

\section{RESULTS}

The results of experimental analysis carried out at the Department of Petroleum Research (DPR) in NNPC Zonal office Kaduna.

The data are presented using the tables below:
TABLE I

PRODUCT SAMPLE: ADUWA OIL

\begin{tabular}{|l|l|}
\hline FLASH POINT $\left({ }^{\circ} \mathrm{C}\right)$ & 190 \\
\hline Viscosity at $100^{\circ} \mathrm{C}(\mathrm{Cst})$ & 16.15 \\
\hline Viscosity at $40^{\circ} \mathrm{C}(\mathrm{Cst})$ & 168.23 \\
\hline Viscosity Index & 96 \\
\hline Compressibility $(\mathrm{Mpa})$ & 1562 \\
\hline pH Value & 8.5 \\
\hline Boiling Point $\left({ }^{\circ} \mathrm{C}\right)$ & 68 \\
\hline Pour Point $\left({ }^{0} \mathrm{C}\right)$ & -35 \\
\hline
\end{tabular}

TABLE II

PRODUCT SAMPLE: ABBRo DOT 3 HydRAULIC FLUID

\begin{tabular}{|l|l|}
\hline FLASH POINT $\left({ }^{\circ} \mathrm{C}\right)$ & 301 \\
\hline Viscosity at $100^{\circ} \mathrm{C}(\mathrm{Cst})$ & 10.2 \\
\hline Viscosity at $40^{\circ} \mathrm{C}(\mathrm{Cst})$ & 132 \\
\hline Viscosity Index & 120 \\
\hline Compressibility $(\mathrm{Mpa})$ & 1700 \\
\hline pH Value & 7.4 \\
\hline Boiling Point $\left({ }^{0} \mathrm{C}\right)$ & 186 \\
\hline Pour Point ${ }^{0} \mathrm{C}$ & -50 \\
\hline
\end{tabular}

TABLE III TEMPERATURE ${ }^{0} \mathrm{C}$

\begin{tabular}{|c|c|c|c|c|}
\hline $\begin{array}{l}\text { Time } \\
\text { minute }\end{array}$ & $\begin{array}{l}\text { Initial } \\
\text { Tempt } \\
{ }^{0} \mathrm{C}\end{array}$ & $\begin{array}{l}\text { Final } \\
\text { Tempt } \\
{ }^{0} \mathrm{C}\end{array}$ & $\begin{array}{l}\text { Change in } \\
\text { Tempt }{ }^{0} \mathrm{C}\end{array}$ & $\begin{array}{l}\text { Average } \\
\text { Change in } \\
\text { Tempt }{ }^{0} \mathrm{C}\end{array}$ \\
\hline 5 & 30.0 & 33.0 & 3.0 & \\
\hline 10 & 33.0 & 35.0 & 2.0 & \\
\hline 15 & 35.0 & 38.0 & 3 & \\
\hline 20 & 38.0 & 40.0 & 2.0 & \\
\hline 25 & 40.0 & 43.0 & 3.0 & $\begin{array}{r}= \\
2.4^{0} \mathrm{C}\end{array}$ \\
\hline
\end{tabular}

Volume of Aduwa oil used $=140 \mathrm{ml}$

5 minutes' interval

Time taken for the application of brake $=3$ seconds

TABLE IV SPEED (R P M)

\begin{tabular}{|l|l|l|l|}
\hline $\begin{array}{l}\text { Initial } \\
\text { Speed } \\
\text { (r.p.m) }\end{array}$ & $\begin{array}{l}\text { Final } \\
\text { Speed } \\
\text { (r.p.m) }\end{array}$ & $\begin{array}{l}\text { Change in } \\
\text { Speed (r.p.m) }\end{array}$ & $\begin{array}{l}\text { Average } \\
\text { Speed } \\
\text { (r.p.m) }\end{array}$ \\
\hline 1400 & 0 & 1400 & \multirow{1}{*}{} \\
\cline { 1 - 3 } 1400 & 0 & 1400 & \multirow{1}{*}{$=140$ r.p.m } \\
\hline 1400 & 0 & 1400 \\
\hline 1400 & 0 & 1400 & \\
\hline 1400 & 0 & 1400 &
\end{tabular}

TABLE V

PRESSURE KGF/CM2

\begin{tabular}{|l|l|l|l|l|}
\hline $\begin{array}{l}\text { Time } \\
(\text { minutes })\end{array}$ & $\begin{array}{l}\text { Initial } \\
\text { Pressure } \\
\left(\mathrm{Kgf} / \mathrm{cm}^{2}\right)\end{array}$ & $\begin{array}{l}\text { Final } \\
\text { Pressure } \\
\left(\mathrm{Kgf} / \mathrm{cm}^{2}\right)\end{array}$ & $\begin{array}{l}\text { Change in } \\
\text { Pressure } \\
\left(\mathrm{Kgf} / \mathrm{cm}^{2}\right)\end{array}$ & $\begin{array}{l}\text { Average } \\
\text { Pressure } \\
\left(\mathrm{Kgf} / \mathrm{cm}^{2}\right)\end{array}$ \\
\hline 5 & 0 & 0.8 & 0.8 & \\
\hline 10 & 0 & 1.0 & 1.0 & \\
\cline { 1 - 4 } 15 & 0 & 1.0 & 1.0 & \multirow{1}{*}{$=1.04$} \\
\cline { 1 - 4 } 20 & 0 & 1.2 & 1.2 & \\
\hline 25 & 0 & 1.2 & 1.2 & \\
\hline
\end{tabular}


TABLE VI

TEMPERATURE $\left({ }^{\circ} \mathrm{C}\right)$

Volume of Aduwa oil used $=140 \mathrm{ml}$

5 minutes' interval

Time taken for the application of brake $=3$ seconds

\begin{tabular}{|c|c|c|c|c|}
\hline $\begin{array}{l}\text { Time } \\
\text { (minutes) }\end{array}$ & $\begin{array}{l}\text { Initial } \\
\text { Tempt }{ }^{0} \mathrm{C}\end{array}$ & $\begin{array}{l}\text { Final } \\
\text { Tempt } \\
{ }^{0} \mathrm{C}\end{array}$ & $\begin{array}{l}\text { Change in } \\
\text { Tempt }{ }^{0} \mathrm{C}\end{array}$ & $\begin{array}{l}\text { Average } \\
\text { Tempt }\end{array}$ \\
\hline 5 & 30.0 & 31.0 & 1.0 & \multirow[b]{5}{*}{$=1.0^{\circ} \mathrm{C}$} \\
\hline 10 & 31.0 & 32.0 & 1.0 & \\
\hline 15 & 32.0 & 33.0 & 1.0 & \\
\hline 20 & 33.0 & 34.0 & 1.0 & \\
\hline 25 & 34.0 & 35.0 & 1.0 & \\
\hline
\end{tabular}

TABLE VII

SPEED (R.P.M)

\begin{tabular}{|c|c|c|c|}
\hline $\begin{array}{l}\text { Initial } \\
\text { Speed } \\
\text { (r.p.m) }\end{array}$ & $\begin{array}{l}\text { Final Speed } \\
\text { (r.p.m) }\end{array}$ & $\begin{array}{l}\text { Change in } \\
\text { Speed } \\
\text { (r.p.m) }\end{array}$ & $\begin{array}{l}\text { Average } \\
\text { Speed } \\
\text { (r.p.m) }\end{array}$ \\
\hline 1400 & 0 & 1400 & \multirow[b]{5}{*}{$=1400$ r.pm } \\
\hline 1400 & 0 & 1400 & \\
\hline 1400 & 0 & 1400 & \\
\hline 1400 & 0 & 1400 & \\
\hline 1400 & 0 & 1400 & \\
\hline
\end{tabular}

TABLE VIII

PRESSURE (KGF/CM $\left.{ }^{2}\right)$

\begin{tabular}{|c|c|c|c|c|}
\hline $\begin{array}{l}\text { Time } \\
\text { (minute) }\end{array}$ & $\begin{array}{l}\text { Initial } \\
\text { Pressure } \\
\left(\mathrm{kgf} / \mathrm{cm}^{2}\right)\end{array}$ & $\begin{array}{l}\text { Final } \\
\text { Pressure } \\
\left(\mathrm{kgf} / \mathrm{cm}^{2}\right)\end{array}$ & $\begin{array}{l}\text { Change in } \\
\text { Pressure } \\
\left(\mathrm{kgf} / \mathrm{cm}^{2}\right)\end{array}$ & $\begin{array}{l}\text { Average } \\
\text { Pressure } \\
\left(\mathrm{kgf} / \mathrm{cm}^{2}\right)\end{array}$ \\
\hline 5 & 0 & 0.5 & 0.5 & \multirow{5}{*}{$\begin{array}{l}= \\
0.62 \mathrm{kgf} / \mathrm{cm}^{2} \\
=\quad 6.1 \quad \mathrm{x} \\
10^{4} \mathrm{~N} / \mathrm{m}^{2}\end{array}$} \\
\hline 10 & 0 & 0.6 & 0.6 & \\
\hline 15 & 0 & 0.6 & 0.6 & \\
\hline 20 & 0 & 0.7 & 0.7 & \\
\hline$\frac{25}{25}$ & 0 & $\begin{array}{l}0.7 \\
.7\end{array}$ & 0.7 & \\
\hline
\end{tabular}

TABLE IX

ACtUATING Force (N) AND TORQUe ABSORB (NM)

\begin{tabular}{|l|l|l|}
\hline & Aduwa oil & Dot 3 hydraulic fluids \\
\hline Actuating force $(\mathrm{N})$ & 3060 & 1830 \\
\hline Torque absorb(Nm) & 306 & 183 \\
\hline
\end{tabular}

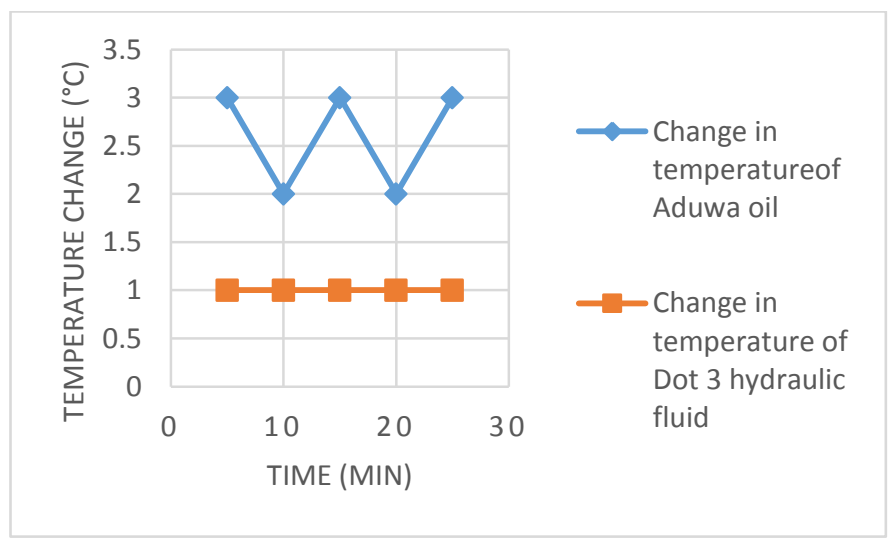

Fig 1. Variation in temperature change with time

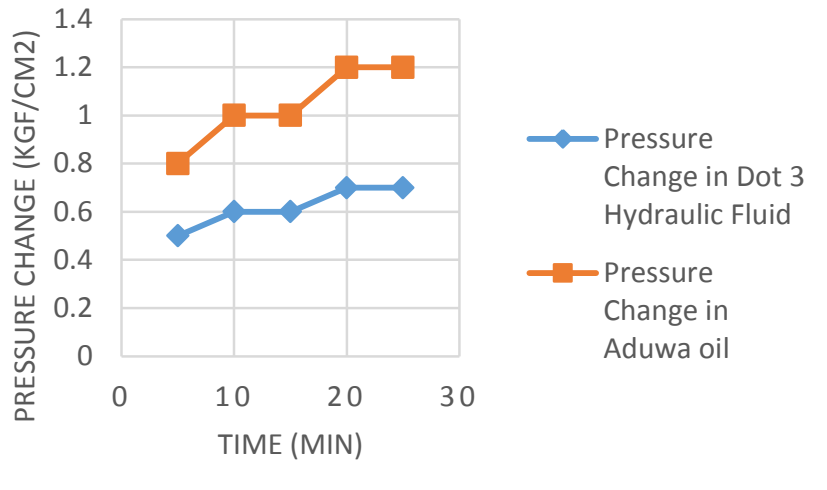

Fig 2. Variation in Pressure change with time

\section{DISCUSSION}

From table I it can be deduced that Aduwa Oil has a low flash point of $190^{\circ} \mathrm{C}$ and DOT 3 hydraulic fluid has a flash point of $301{ }^{\circ} \mathrm{C}$. This indicates that Aduwa oil will ignite in air readily than DOT 3 hydraulic fluid. The flash point of Aduwa oil satisfies the ISO Standard for hydraulic fluids.

From the result presented (Table I and II) the viscosity of Aduwa oil is 16.15 and 168.23 at $100^{\circ} \mathrm{C}$ and $40^{\circ} \mathrm{C}$ respectively while that of DOT 3 hydraulic fluid is 10.2 and 132 at the same temperatures. From the definition of viscosity, it indicates that DOT 3 hydraulic oil flows freely than Aduwa oil at same observed temperatures.

From table 1a and $1 \mathrm{~b}$ the viscosity index of Aduwa oil is 96 while that of DOT 3 hydraulic fluid is 120 . A high viscosity index value is generally desirable since its denotes an oil whose viscosity does not change greatly with temperature, with the values from the tables, DOT 3 hydraulic oil will be desired than Aduwa oil on the bases of viscosity index value.

The $\mathrm{pH}$ values for both Aduwa oil and DOT 3 hydraulic fluid falls within the acceptable range for brake fluids.

Aduwa oil has a low boiling point of $\left(68^{\circ} \mathrm{C}\right)$ than DOT 3 hydraulic oil $\left(186^{\circ} \mathrm{C}\right)$ indicating that with a little rise in temperature Aduwa oil will boil i.e. it cannot be applicable at high temperature condition.

From the result in table 1a and $1 \mathrm{~b}$ Aduwa oil has a pour point of -35 and that of DOT 3 hydraulic fluid is -50 . This shows that DOT 3 hydraulic oil will operate in lower temperature than Aduwa oil.

From tables $2 \mathrm{a}$ and $2 \mathrm{~b}$, the average change in temperature for Aduwa oil is $2.4^{0} \mathrm{C}$ while for DOT 3 hydraulic fluid is $1.0^{\circ} \mathrm{C}$. This shows that the thermal conductivity of Aduwa oil is higher than that of hydraulic oil.

This implies that for a given time interval there is an increase in temperature which is directly proportional.

From tables $2 \mathrm{c}$ and $3 \mathrm{c}$, the pressure change for Aduwa oil is higher than that of DOT 3 hydraulic fluids. This indicates that more force is required to bring accelerating body to rest when Aduwa oil is use as brake fluid while less force is required when DOT 3 hydraulic fluid is use. Pressure is proportional to force i.e.

$\mathrm{P}=\mathrm{F} / \mathrm{A}$. 
It indicates that less pressure is applied at the brake pedal to stop the motion when using DOT 3 hydraulic fluid whereas greater pressure is applied to stop the motion when using Aduwa oil.

From table 4, the actuating force for Aduwa oil and DOT 3 hydraulic fluid are $3060 \mathrm{~N}$ and $1830 \mathrm{~N}$ respectively. The values show that Aduwa oil possesses high actuating force than DOT 3 hydraulic fluid. This means that more force will be required for braking to occur when using Aduwa oil than when using Abbro Dot 3 hydraulic fluid.

The energy or heat dissipated indicates that more energy is given out when Aduwa oil is used as brake fluid than DOT 3 hydraulic fluid. This implies that Aduwa Oil in it raw form is not good as a brake fluid but if some additives are added to reduce its viscosity, it may be use as a good brake fluid.

Fig 1 and 2 shows the graphical representation of Temperatures against Time for both Aduwa oil and DOT 3 hydraulic fluids. This implies that for a given time interval there is an increase in temperature which is in direct proportion.

\section{CONCLUSION}

It was observed that the properties of hydraulic fluid signify how effective a fluid or oil will function as brake fluid. From our major findings on hydraulic properties of Aduwa oil; viscosity at $40^{\circ} \mathrm{C}(168.23 \mathrm{cst})$ and at $100^{\circ} \mathrm{C}(16.5 \mathrm{cst})$ : viscosity index 96 , flash point $190^{\circ} \mathrm{C}$, compressibility $1562 \mathrm{Mp}$, boiling point $68 \mathrm{C}$, pour point $-35^{\circ} \mathrm{C}$. it was observed that Aduwa oil have high internal friction resistance at lower temperature than DOT 3 hydraulic fluid, because the viscosity of Aduwa oil is higher (168.23cst) than DOT 3 hydraulic fluid (132cst) at $40^{\circ} \mathrm{C}$. Aduwa oil will also ignite at lower temperature compared to DOT 3 hydraulic fluid, because the flash point of Aduwa oil is $190^{\circ} \mathrm{C}$ and $301 \mathrm{C}$ for DOT 3 hydraulic fluid. Aduwa oil will seize to flow at a lower temperature of $-35^{\circ} \mathrm{C}$ below which DOT 3 hydraulic fluid can flow, because it has a lower pour point of $-50^{\circ} \mathrm{C}$. Aduwa oil has a lower boiling point $\left(68^{\circ} \mathrm{C}\right)$, this show that it boils readily at lower temperature where is a good functional hydraulic fluid is said to have a very high boiling point so as to enable it perform effectively at an elevated temperature. Aduwa oil is alkaline with ph value of 8.5 whereas DOT 3 hydraulic fluid is slightly alkaline with ph value of 7.4. The actuating force of Aduwa oil is $3060 \mathrm{~N}$ which is higher than that of DOT 3 hydraulic fluid which has $1830 \mathrm{~N}$, this implies that more force will be required for braking to occur when using Aduwa oil than DOT 3 hydraulic fluid. The torque absorbed by Aduwa oil is $306 \mathrm{Nm}$ which is higher than that the torque absorbed by DOT 3 hydraulic fluid (183Nm).

Based on the already made observation and findings of this study, the following implications emerged;

- It is a sluggish fluid.

- It is an alkaline fluid.

- It has readily low boiling point.

- It requires a high operating pressure of brake pedal.

\section{Nomenclature}

$F_{t}=$ Actuating Force $(\mathrm{N})$

$N=$ Speed of electric Motor (r.p.m) $t=$ Time (s)

$A=$ Area of drum $\left(\mathrm{m}^{2}\right)$

$r=$ radius of drum $(\mathrm{m})$

$d=$ diameter of drum $(\mathrm{m})$

$E=$ Energy absorb $(\mathrm{J})$

$T=$ torque $(\mathrm{N}-\mathrm{m})$

ISO =International Standard Organization.

\section{REFERENCES}

[1] Abu-AL-Futuh (1989). Study on the processing of balaniesaegyptiaca fruits for food drug and feed. In new crop for food and indstury, wickene G.E., Hag, N and Day, (editors). Champman and Hall London. Pp 272278.

[2] Abu-AL-Futuh (1983). Balanities aegypticaca; and unutilized Raw material potential for Agro industrial Exploitation. Reports, UNDIODO/10,494, R-83-543 25 order No. PB84-131085, UNIDO, Vienna. PP.

[3] Judson. Hale, Tirado Thomas and Michael.T.Ghiselin (1999), history of hydraulics article,(volume 6).

[4] Keay, R.W.J. and stanfiled, D. (1964). Nigeria pres department of forest Research, Ibadan. Pp 250-405

[5] Khurmi R.S. and Gupta J.K. (1976) fluid power. chand publishers Pp 914-946

[6] Khurmi R.S. and Gupta J.K. (1976) machine design. chand publishers Pp 857-912

[7] Michel (2004): Trees, shrubs and lianas of west African dry zones. The Netherlands: Cirad Margaret publisher pp 190.

[8] Okoye, W.E, Okobi A.O. Okonkwo, E. (1999): Extraction and characterization of oils for nine lesser known Nigerian oil seeds. In processing $23^{\text {rd }}$ annual NIFST conference, $25^{\text {th }}-29^{\text {th }}$ October. Pp 231-233

[9] Onyemachi, S.E. and Obanewo, O.S. (1992): Aduwa (Balanites aegyptiaca) a potential source of vegetable oil. Inagro-industrial processing of fruits and vegetables. North Eastern Chapter of Nigeria institute of food science and technology proceedings 2. 94-99

[10] Oyemach, S.E. and Obanawo, O.S. (1998 Characteristics of oil from Aduwa (Balanites aegyptiaca): Journal of applied since and management 2:50-51 